\title{
8 ニュース
}

\section{建設産業・材料の将来展望}

\author{
阿部道彦 ${ }^{* 1} \cdot$ 宇治公隆 ${ }^{* 2} \cdot$ 野口貴文*3 $\cdot$ 並木 哲*4
}

\section{1.はじめに}

日本学術振興会・建設材料第 76 委員会（以下， 76 委 員会）は分野間の壁を越えた研究者・技術者が一堂に会 し，建設材料に関する最先端の技術や問題点について情 報・意見の交換を行い, 今後の技術開発の手法, 方向性, 在り方等について総合的に研究することを目的に，昭和 19 年 10 月に設立された。委員構成は学界 50 名, 産業 界 61 名からなり精力的な委員会活動を行っている。

これまで 76 委員会の活動として，その時々の話題を 取り上げ，年間 6 回のシンポジウム, パネル討論会, 見 学会を開催し, 平成 23 年 3 月 2 日のパネル討論会で 400 回を迎えた。第 400 回の議題は「建設産業の将来展 望」をテーマに講演 3 編, および「建設材料の将来展望」 をテーマにパネル討論を行ったので, ここにその内容を 紹介する。

2. 講 演

講演は, 学界, 企業, マスコミの各分野から, 建設業界 の将来についてのものであった。その一部を紹介する。

(1)東京大学教授・國島正彦氏より, 公共工事の受発注 に関する歴史的経緯と現状，日本と国際標準の違い，安 定成長の時代における日本の国際標準への道について解 説があった。

・日本における新設工事は少なくなるが，5～12\%の社 会基盤施設投資が見达めるため，国内にもまだマー ケットがあると言える。

・日本の技術者はお金を污いものと考えており，他の国 と比べて技術者の経済面・経営面に関する能力が低い。 (2)鹿島建設副社長・金子宏氏より，建設業の現状，将 来市場, 海外での取組み, 都市再生・再開発, 既存建物 の再活用，多様化する建築ニーズへの技術対応，建築業 界を取り巻くその他の動向について解説があった。

・建設投資の減少の割に業者や就業者の減少量が少ない

*1 あべ・みちひこ／工学院大学 建築学部建築学科 教授 (正会員)

*2 うじ・きみたか /首都大学東京 大学院都市環境科学研究科 都 市基盤環境学域 教授 (正会員)

*3 のぐち・たかふみ/東京大学 大学院工学系研究科 建築学専攻 准教授 (正会員)

*4 なみき・さとる/大成建設(株) 技術センター 建築構工法研究室 材料チーム（正会員）
ため過当競争となっており，賃金低下につながっている。 ・建設業は現在，若者に魅力のない産業となっている。

・日本国内の経済活動が活発な状態になれば市場はまだ まだある。

・海外の仕事はリスクが大きいため, 契約をしっかりやる 必要がある。海外に行ける人間の育成や海外に進出し た際の運営方法について考えていかなければならない。

(3)日経 BP 社建設局編集委員・西村隆司氏より，建設 業の存在感について考える上で，一般の人は建設業のこ とをどのように捉えているか，いかに魅力を向上してい けばよいかについて解説があった。

・建設業に就職する学生が減少している。建設業の労働 環境は厳しいが, 賃金水準は悪くない。しかし, 労働 負荷に対する賃金は低い。

・今の若者は海外進出志向が強い。

・インフラの更新は, 建設業界にとってチャンスである。 インフラの老朽化が問題になっていることは, 社会も 認識しつつあるが, メディアに映る建設業の対応が事 後対応になっている印象が強い。

・これからは市場が作られるのを待つのではなく自ら創 造する必要があり，経営戦略が問われることになる。

3. パネル討論会

講演の後, コーヒーブレイクをはさんで, パネル討論 会を行った。司会の東京大学准教授・野口貴文より，こ のパネル討論会で気概あるコンクリート系の若い先生方 に将来について活発に語ってもらい, 建設材料の今後の 新しい目を見出していきたい，という挨拶があった。

パネラーは表-1 に示す 6 名の若手の大学教員である。

研究と建設現場〜土木の視点から〜（佐川氏）

研究と建設現場ということで，材料の耐久性評価やそ

\begin{tabular}{c|l|l}
\multicolumn{2}{c}{ 表-1 パネラー } & \multicolumn{1}{c}{ (敬称略) } \\
\hline \multirow{2}{*}{ 土木分野 } & 九州大学 & 佐川康貴 \\
\cline { 2 - 3 } & 名古屋大学 & 国枝 稔 \\
\hline \multirow{2}{*}{ 建築分野 } & 東京理科大学 & 兼松 学 \\
\cline { 2 - 3 } & 名古屋大学 & 丸山一平 \\
\hline \multirow{2}{*}{ 化学分野 } & 東京工業大学 & 新 大軌 \\
\cline { 2 - 3 } & 東京工業大学 & 齋藤 豪 \\
\hline
\end{tabular}


の事例について紹介があり，次のコメントがあった。

·工期重視で耐久性を犠牲にしていないか。

・同じ材料を使っても施工が違うと性能は違うのではな いか。新しい技術や材料が出てきた時に同じ土俵の上 で評価していいのか。

、材料づくりに必要なもの（国枝氏）

ものづくりの面白さ，国際化の動き，建設材料のあり 方, 建設材料工学で何を教えるか, について解説があり, 次のコメントがあった。

・日本企業は新しい分野について海外の企業の後追いで 参入しているのが現状である。

・途上国で技術をアピールするだけではだめである。

建設材料の将来展開（兼松氏）

材料の将来, 建築物の耐久性・維持管理, 既存構造物 への対応, 建築物の超長期耐久性, 環境問題への貢献に ついて解説があり，次のコメントがあった。

・社会情勢とコンクリート産業構造の関係性を鑑みる に，将来は決してバラ色ではない。

・環境問題における材料の役割が薄い。環境問題が一段 落した後に, 材料の次のステップは何か。

建設材料の将来展開（丸山氏）

解析 (数值解析) と実験, 研究と建設現場, 環境問題 への貢献, 新材料開発について解説があり, 次のコメン トがあった。

・新しい価值を作るための実験・解析が求められる。建 築物の安全率は無駄ではなく価值である。

・天然エネルギーを使って新しいものをどんどん作る社 会であれば，長く構造物を使用することと新しいもの を使用することが同義になるだろう。

○セント化学の役割（新氏）

セメントの需給の変化，セメントにおける循環型資源 利用量および化学組成の変化，二酸化炭素排出削減，今 後のセメントの材料設計について解説があり，次のコメ ントがあった。

・セメントの使用量の減少に伴い循環型資源の使用が低 下しているのが現状である。

・セメントに対する廃棄物割合を増やすと鉱物組成が変 わってくるだろう。廃棄物を有効に利用することで低 炭素化を実現していける。

社会環境材料としてのセメント系材料（齋藤氏）

建設産業の将来展開に先立ち, 近藤先生 ·大門先生の 研究活動について紹介があり，氏自身の「セメント化学 者」としての将来進むべき道などについて意見が述べら れ，次のコメントがあった。

・近藤・大門研では, セメント化学の観点からコンクリー 卜を改善しようという意識があったのではないか。

討論の要旨（会場を交えての討論）

(1)コンピュータを使った解析で現象を表現することは できるが, 将来を保証してはくれない。現場と研究につ

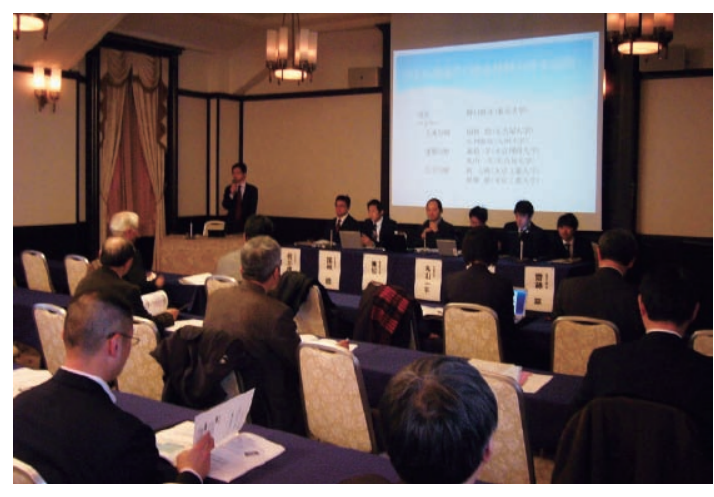

写真-1 パネル討論会

いて今の問題について克服するためにどのように取り組 んでいるのかについて議論がなされた。

·室内試験・促進試験は実環境の何倍の促進になるのか という問いに関する明確な回答は出ていない。

・解析結果をどれくらい保証できるのか断言できる人は いない。リスクはあるものの, 数值解析をうまく使っ ていくしかない。

・解析には，我々が見ることができない部分を見ること ができる点に意味がある。

・超長期の耐久性を考えたりする場合には解析は必ず行 う必要がある。解析の精度を高めていくのが自分の仕 事であると考えている。

(2)日本の建設業界・コンクリート業界・セメント業界 は他の国に比べると材料開発という点で後塵を扯しつつ あるのではないか。これへの打開策についてどのように 考えているかについて議論がなされた。

・セメント産業は循環型材料を受け入れていて, 燃料や 原料として使っている。循環型社会においては不可欠 である。建設材料の新展開とは建設以外にセメントを 使うということになるのではないか。

・自動車や燃料電池といった活力のある研究と違いセメ ント分野はスピード感がない。また，海外のスピード とも差がある。

・新しいものを作っても，日本国内では実績がないと使 用したい時に使えない。

・発想が遅いために日本は研究で後れをとっているので はないか。面白いと思ったらやってみよう。

以上のように, パネラーのみではなく, 会場も含めて 活発な討論がなされた。

4.おわりに

東日本大震災は，日本史上かつて無い未曾有の大危機 をもたらした。建設業は，安全で安心できる社会を提供 する産業であり，建設材料はその要となるべきものであ る。そして，コンクリートは最重要な役割を担うべき 建設材料であり，「コンクリート工学」誌の読者に今後 も 76 委員会の活動について, 可能な限り情報を発信し ていく予定である。 